\title{
Municipal-private partnership as a tool for developing the economy of a single-industry mining city
}

\author{
Tatyana Yakushina ${ }^{1}$, and Evgeny Shvakov ${ }^{2}$ \\ ${ }^{1}$ Head of the training and advanced training sector of the personnel training and development Center, \\ JSC SUEK-Kuzbass, 652507 Leninsk-Kuznetsky, Russia \\ ${ }^{2}$ Altai state University, 656049 Barnaul, Russia
}

\begin{abstract}
The problem of development of single-industry municipalities is one of the most acute in the modern economy. Single-industry municipalities are characterized by limited opportunities and significant development risks. The dependence of the economy of a multi-profile settlement on the activities of the city-forming enterprise necessitates the search for mechanisms for their mutually dependent development. This mechanism is a municipal-private partnership. The article considers new approaches to the implementation of municipal-private partnership in relation to the conditions of a single-profile municipality. The approaches proposed in the article to the organization of municipal-private partnership are designed to create conditions for the development of the city-forming enterprise, the sectors of the municipal economy associated with its activities, as well as the social sphere of the municipality. The article describes in detail the tools of municipal-private partnership that ensure the development of the investment potential of the city-forming enterprise, entrepreneurship in the municipality and corporate social responsibility.
\end{abstract}

\section{Introduction}

One of the modern problems of economic science and practice is the problem of development of single-industry settlements or single-industry towns. It should be recognized that this applied problem is equally acute, both in the Russian Federation and abroad [1].

The problem of single-industry towns in the Russian Federation appeared with the transition to a market economy. In the conditions of the socialist mode of production, the pace of development of the vast majority of single-industry towns was higher than the average. At the expense of the city-forming enterprise, not only economic but also social and environmental problems of single-industry towns were solved. Therefore, it is no accident that the first theoretical research on single-industry towns appeared in foreign economic science. These studies became the basis for subsequent theoretical research. One of the first scientists to study the problems of single-industry towns is J. Allen, author of the study "Company Town in the American West ". He studied the development of coal-mining, oil-producing, and timber-producing cities in America, which were due to the 
industrialization of the economy. Such cities are characterized by isolation and centrality in relation to the city-forming enterprise. He is the author of the term "company town" [2]. The same term is used in the works of J. garner in the analysis of single-industry towns in New England [3]. A little later, the concepts of "single industry town" or "one industry town" - "city of one industry" appear in foreign economic theory. In this case, the specialization of such cities was often indicated. On the basis of this, the terms appeared: "minig town" - mining, "railway town" - railway transport," college town " - educational services at a major University," lumber towns " - wood production [4,5]. The analysis confirms

Modern Russian science uses the concept of" single - industry city "(ancient Greek" monos " - one, the only one), which became the basis for the formation of a unified methodological base for systematic research and analysis of this economic phenomenon.

\section{Results and discussion}

Currently, there are 319 single-industry towns in the Russian Federation. More than 13 million people live in these cities. The employed population in single - industry towns is 5.8 million people, while $16.7 \%$ are employed in city-forming enterprises that produce $1 / 5$ of the total volume of shipped industrial products in the Russian Federation, or 7.1 trillion rubles a year.

Given the acute socio-economic problems of development of monotowns of the Russian Federation in 2016 in the framework of state support of development of single-industry towns was developed and approved priority program "Integrated development of towns". The purpose of this program was to create conditions that reduce the dependence of singleindustry municipalities on the activities of city-forming enterprises. Achieving this goal in accordance with the program passport was achieved by creating new jobs and improving the quality of the urban environment. All single-industry towns have been developed and implemented the municipal program of development of monotowns, the measures to support small and medium enterprises, development of industrial and social infrastructure of these towns.

The state has put in place a number of channels for financing measures to stabilize the situation of single-industry towns.

1. Was created trust funds. The single-industry towns development Fund, created by Vnesheconombank, invests money in training officials, roads, water supply and sanitation, creating a comfortable urban environment for residents of single-industry towns, repairing Central streets of cities, and creating industrial parks by financing roads, power grids and other engineering infrastructure.

2. The Federal Corporation for the development of small and medium-sized businesses (SME Corporation) was Established. The innovation of the SME Corporation was the creation of A business Navigator portal, which allows you to open your business in five steps, calculate a business plan, get information about credit products, government support measures, and participation in public procurement. The Stream technology platform provides a business start-up with a quality website and tools for its promotion. Currently, the SME Business Navigator Portal is successfully operating in 169 major Russian cities. As of may 2017, the system has already registered more than 70 thousand users from various regions of Russia.

3. Regional programs have been Adopted and subsidies have been provided for part of the costs of small and medium-sized businesses related to the payment of the first installment when concluding an equipment leasing agreement with Russian leasing organizations, measures of tax incentives for business, state guarantees and subsidies for 
manufacturing companies. The regional budget subsidizes the cost of building engineering infrastructure and paying interest on loans for technological re-equipment of the enterprise.

4. Other targeted Federal programs for financing industry and agriculture, such as the industrial development Fund and special investment contracts (SPIC), which provide preferential treatment to investors for up to 10 years.

As a result of implementation of the program "Integrated development of towns" and support single-industry towns through the creation of areas of advancing socio-economic development (TOSER created 100 single-industry towns) were formed new avenues for business development.

At the end of 2018, this program was urgently curtailed, without achieving its goal. In this regard, the problem of development of single-industry towns in Russia remains relevant to this day. The remaining problems of development of single-industry towns in the Russian Federation determine the need to find new ways and ways to solve them.

One of the possible approaches to the development of the economy of a single-industry city is its diversification with the gradual overcoming of mono-industry. This approach involves the active development of economic activities that differ from the profile of the city-forming enterprise. It is planned to expand the range and nomenclature of goods produced by the city's enterprises, develop industrial and social infrastructure, increase the share of small and medium-sized businesses in the total volume of production, and actively introduce innovative technologies in the production and service sector. It should be noted that diversification of economy of monocities can be based on the diversification activities of city-forming enterprise. This approach also assumes that a single-industry city and/or city-forming enterprise has the potential to diversify its activities and implement support measures for the development of new types of economic activities, including financial ones. The implementation of this approach is based on the use of municipal-private partnership mechanisms.

One of the typical single-industry towns in Russia is Leninsk-Kuznetsky, whose economy requires diversification. This city is located in the West of the Kemerovo region. According to the classification of single-industry towns adopted in the Russian Federation, Leninsk-Kuznetsky is one of the monoprofil municipalities where there are risks of deterioration of the socio-economic situation. The distance from Leninsk-Kuznetsky to Moscow is 3,200 km, to the regional center (Kemerovo) $-90 \mathrm{~km}$, to the largest cities of Western Siberia (Novosibirsk, Tomsk, Barnaul) - within 250-350 km.

Currently, 97.4 thousand people live in the municipality of Leninsk-Kuznetsky city district. Of this number, the vast majority live in urban areas (97.8\%) and just over 2000 thousand in rural areas. Over the past 5 years, the population of the municipality has decreased by $3.5 \%$. The decline in the population has become a steady trend in the development of the municipality.

The main natural wealth of the municipality is coal. Being in the geographical center of the Kuznetsk coal basin, the city's economy is specialized in coal mining. Mining branches of mines occupy $65-70 \%$ of the territory of Leninsk-Kuznetsky city district. Most of the extracted coal is used in the energy sector, while a smaller part is used in metallurgy (coking). The coals of some formations can be used to produce liquid fuel.

The city of Leninsk-Kuznetsky is located at the intersection of highways connecting the South and North of the Kemerovo region. There are three railway stations located in the city. All stations are freight-based in nature. The main cargo is coal.

The modern development of the city is closely connected with the development of coal mining enterprises. In the structure of industrial production of the city, the coal industry occupies about $70 \%$. About 12.7 thousand people, or $26.5 \%$ of the total number of people employed in the economy, are employed in the industry profile for the city (table 1). 
Table 1. Activity of enterprises of Leninsk-Kuznetsky city district, million rubles.

\begin{tabular}{|c|c|c|c|c|c|}
\hline Indicators & $\mathbf{2 0 1 5}$ & $\mathbf{2 0 1 6}$ & $\mathbf{2 0 1 7}$ & $\mathbf{2 0 1 8}$ & $\mathbf{2 0 1 9}$ \\
\hline $\begin{array}{c}\text { Shipped goods of own } \\
\text { production, performed works and } \\
\text { services on their own (without } \\
\text { small businesses), total }\end{array}$ & 36755.1 & 48444.7 & 55187.5 & 69532.7 & $\ldots$ \\
\hline Including mining & $\ldots$ & $\ldots$ & $\ldots$ & 51758.5 & $\ldots$ \\
\hline Profit (loss) before tax last year & 670.6 & 14378.3 & 28121.4 & 38896.8 & 29497.2 \\
\hline Including mining & $\ldots$ & 14216.7 & $\ldots$ & 38475.1 & 29094.3 \\
\hline $\begin{array}{c}\text { Investments in fixed assets at the } \\
\text { expense of the municipal budget }\end{array}$ & 333.3 & 267.1 & 153.4 & 80.2 & $\ldots$ \\
\hline $\begin{array}{c}\text { Investments in fixed capital made } \\
\text { by organizations located on the } \\
\text { territory of the municipality } \\
\text { (without small businesses) }\end{array}$ & 5088.9 & 5296.8 & 8463.3 & 10432.5 & $\ldots$ \\
\hline $\begin{array}{c}\text { Investments in fixed capital of } \\
\text { municipal organizations }\end{array}$ & 719.1 & 298.0 & 75.3 & 215.9 & $\ldots$ \\
\hline
\end{tabular}

This situation is typical for coal-producing regions not only in the Russian Federation, but also in other countries $[6,7,8]$.

On the territory of the Leninsky-Kuznetsky city district, the only company in the extractive industry operates - a subsidiary of the Siberian coal energy company, SUEKKuzbass. This company is the city-forming one for the Leninsky-Kuznetsky city district.

It is the activity of JSC SUEK-Kuzbass that determines the current state and prospects of development of Leninsk-Kuznetsk city district. Its share of the total size of a singleindustry city is:

$-74.4 \%$ of the volume of shipped goods of own production;

- $98 \%$ or more of the profit received by enterprises in the region;

- $97 \%$ or more of investment.

In addition, the share of revenues of the city-forming enterprise is $30 \%$ of its own budget revenues.

The analysis clearly shows the correlation between the development of LeninskKuznetsk city district and JSC SUEK-Kuzbass. This circumstance makes it necessary to develop a coherent policy for the development of a municipality and a city-forming enterprise [9] within the framework of municipal-private partnership mechanisms, which are presented in table 2 .

Table 2. Directions of municipal-private partnership for the development of single-industry towns.

\begin{tabular}{|c|c|c|}
\hline $\begin{array}{c}\text { Direction of } \\
\text { activity }\end{array}$ & Content of activity & $\begin{array}{c}\text { Roles of a municipality and a city-forming } \\
\text { enterprise }\end{array}$ \\
\hline $\begin{array}{c}\text { Development of the } \\
\text { investment potential } \\
\text { of the city-forming } \\
\text { enterprise }\end{array}$ & $\begin{array}{c}\text { Implementation of projects for } \\
\text { the development of investment } \\
\text { potential elements used in the } \\
\text { production activities of the city- } \\
\text { forming enterprise }\end{array}$ & $\begin{array}{c}\text { The initiator of the measures is the } \\
\text { municipality. }\end{array}$ \\
$\begin{array}{c}\text { Financing of events is provided by the } \\
\text { municipality. }\end{array}$ \\
The user is a city-forming enterprise. \\
\hline
\end{tabular}




\begin{tabular}{|c|c|c|}
\hline $\begin{array}{c}\text { Development of } \\
\text { small businesses } \\
\text { associated with the } \\
\text { activities of the city- } \\
\text { forming enterprise }\end{array}$ & $\begin{array}{c}\text { Creation of small satellite } \\
\text { enterprises of the city-forming } \\
\text { enterprise. Small businesses } \\
\text { take on the functions of separate } \\
\text { services of the city-forming } \\
\text { enterprise. }\end{array}$ & $\begin{array}{c}\text { The initiator of the implementation of measures } \\
\text { is a joint decision of the city-forming enterprise } \\
\text { and the municipality. }\end{array}$ \\
\hline $\begin{array}{c}\text { Implementation of } \\
\text { corporate } \\
\text { responsibility } \\
\text { measures of the } \\
\text { city-forming } \\
\text { enterprise }\end{array}$ & $\begin{array}{c}\text { Implementation of measures to } \\
\text { businesses-municipal entity. } \\
\text { create social infrastructure } \\
\text { facilities, initiatives to improve } \\
\text { the social environment and } \\
\text { environmental situation in the } \\
\text { municipality }\end{array}$ & $\begin{array}{c}\text { The initiator of the implementation of measures } \\
\text { is the city-forming enterprise. }\end{array}$ \\
$\begin{array}{c}\text { Event financing is a city-forming enterprise. } \\
\text { The user of the created objects is the } \\
\text { municipality. }\end{array}$ \\
\hline
\end{tabular}

The proposed tools can also be used when creating territories of advanced development in single-industry towns [10].

As part of the implementation of municipal-private partnership initiatives to develop the investment potential of the city-forming enterprise, it is necessary to determine the areas of responsibility of the municipality and the city-forming enterprise [11]. The most logical way to correlate the areas of responsibility of subjects of municipal-private partnership with the structure of investment potential. As its main elements (structural components) of investment potential, the following can be identified:

- financial potential (a set of monetary resources and highly liquid financial assets that can be used in investment activities);

- production potential (a set of tangible and intangible assets accumulated by an industrial enterprise as a result of production activities);

- resource and raw material potential (provision of balance reserves of the most important types of natural resources that can be used by an industrial enterprise in its production activities);

- infrastructure potential (conditions that characterize the level of development of industrial and social infrastructure in the area where the industrial enterprise is located);

- institutional potential (availability of necessary institutions of the market economy, conditions that characterize the development of financial and credit institutions, consulting, Advisory and other organizations);

- personnel potential (availability of professionally trained labor force and engineering and technical personnel, conditions for training the necessary personnel in the region);

- intellectual potential (the educational level of the population, the ability to retrain staff, the degree of development of R \& d, etc.);

- innovation potential (the measure of implementation of scientific and technological progress and the degree of modernization of production).

The city-forming enterprise makes efforts to accumulate financial, production, resource, raw materials and innovation components. Municipal authorities take measures to develop the infrastructure, institutional, human and intellectual components of the investment potential of the city-forming enterprise, creating conditions for the development of industrial and social infrastructure, the formation and development of human capital, etc. It is important that the municipal-private partnership act as part of the implementation of a specific investment project to develop (expand) the activities of the city-forming enterprise. In this case, the municipal-private partnership becomes meaningful and concrete, and its effectiveness increases.

The city-forming enterprise within the framework of a municipal-private partnership is responsible for the cost filling of the investment potential and provides:

- increase in the amount of financial resources generated from own and attracted sources; 
- expansion of production capacities (increase in production areas, expansion of the fleet of vehicles, increase in the cost of equipment):

- formation of a pool of the company's rights to land plots, water intake and water supply facilities, mineral deposits, etc. necessary for the project implementation;

- securing the necessary intellectual property rights for the enterprise.

The task of a city-forming enterprise is to accumulate at its disposal material and nonmaterial resources suitable for subsequent investment.

The municipality, represented by the relevant authorities, creates the necessary conditions for the implementation of an investment project by developing components of the investment potential, the rights to which do not belong to the city-forming enterprise. Within its competence, the municipality implements measures to:

- development of the infrastructure component of the investment potential (development of the infrastructure of the municipality necessary for the city-forming enterprise to implement an investment project: laying new or repairing existing roads and Railways, development of telephone and satellite communication networks, development of energy supply, gas supply, water supply, drainage, etc.);

- development of the institutional component of the investment potential of the enterprise (support of Internet sites; creation of information and analytical and consulting centers on attracting investment; holding conferences with potential investors; participation in national and international investment forums, symposiums, exhibitions, conferences; providing consulting support to the enterprise on any issues of investment activity; resolving individual issues with the regulatory authorities of the region; creating a "single window" system that provides services to investors in interrelated areas of investor functioning in one place).

- development of the human and intellectual component of investment potential (financing of training of the local population in educational institutions of the region and the country in the areas of training and programs, in accordance with the needs of the city-forming enterprise).

In the development of entrepreneurship, it is necessary to coordinate the positions of the municipality and the city-forming enterprise regarding the need to develop specific business structures in the municipality. It is important that the services that will be provided by small businesses are in demand by the city-forming enterprise. These small business entities can be:

- recruitment agencies that ensure the selection of personnel for the city-forming enterprise, both in the territory of presence, and personnel working on a shift basis;

- logistics companies and centers that provide intermediary services for the purchase and delivery of necessary materials for the city-forming enterprise;

- trading houses that provide services for the sale of certain types of products of the cityforming enterprise (especially if these are related products sold on the regional market);

- centers for retraining and advanced training that provide educational services for training personnel of the city-forming enterprise;

- others (including the functionality of the city-forming enterprise that is" deducible " from its scope in terms of economic feasibility).

The role of the municipality is to provide financial support to small businesses that are being created using existing tools (grant support, micro-credit, preferential provision of use of municipal property, etc.).

The task of the city-forming enterprise is to provide these small business entities with orders.

Corporate social responsibility is a standard form of support for the development of single-industry towns $[12,6,7]$. SUEK-Kuzbass JSC has considerable experience in this 
field. Previously implemented initiatives of JSC SUEK-Kuzbass concern all aspects of life of the population of Leninsk-Kuznetsk city district. They are shown in table 3.

Table 3. Projects implemented by SUEK-Kuzbass JSC within the framework of corporate responsibility.

\begin{tabular}{|c|c|}
\hline Field of activity & Implemented initiatives \\
\hline $\begin{array}{l}\text { Environmental } \\
\text { protection }\end{array}$ & $\begin{array}{c}\text { Modernization of treatment facilities at A.D. Ruban mine. } \\
\text { Monitoring of the state of biodiversity of rivers in the territory of } \\
\text { presence. } \\
\text { Project to clean up the Kuznetsky Alatau nature reserve from } \\
\text { garbage. }\end{array}$ \\
\hline $\begin{array}{l}\text { Pre-school education } \\
\text { and education }\end{array}$ & $\begin{array}{c}\text { Projects: } \\
\text { "Our new kindergarten»; } \\
\text { "New educational technologies: from kindergarten to school»; } \\
\text { "Building leadership and entrepreneurial skills»; } \\
\text { The Internet-Olympiads in physics and mathematics; } \\
\text { "Course of the young leader»; } \\
\text { "The younger generation-the trajectory of success". }\end{array}$ \\
\hline $\begin{array}{l}\text { Health and social } \\
\text { services }\end{array}$ & $\begin{array}{l}\text { Dream Skis project (rehabilitation and socialization of people with } \\
\text { cerebral palsy, autism, down syndrome, vision and hearing } \\
\text { disorders through skiing) }\end{array}$ \\
\hline $\begin{array}{l}\text { Physical education and } \\
\text { sports }\end{array}$ & $\begin{array}{l}\text { Children's sports day for children of employees of "Olympians- } \\
\text { SUEK» }\end{array}$ \\
\hline Culture & $\begin{array}{l}\text { Organization of tours of the capital's theaters and famous artists on } \\
\text { the territory of their presence. } \\
\text { Financing of events within the framework of celebrating national } \\
\text { and professional holidays in the territory of the company's } \\
\text { presence. }\end{array}$ \\
\hline
\end{tabular}

Today, SUEK-Kuzbass JSC pays considerable attention to solving social and environmental problems in the territory of its presence. In accordance with the "Responsible leadership" rating (assessment of corporate social responsibility), the company is in the "B+" category with a positive Outlook. Among the company's most important tasks is to create a favorable social environment in the regions where it operates.

As part of a municipal-private partnership, the corporate social responsibility program requires discussion and approval by the municipal authorities. At the same time, the following should be designated as priorities of the program:

- creation of social infrastructure facilities funded by the city-forming enterprise (kindergarten, sports facilities, etc.);

- creation of social entrepreneurship entities with financing of their activities;

- projects involving the creation of new jobs at municipal enterprises (including temporary ones);

- projects requiring the provision of funded services (works) subjects of the municipal economy.

\section{Conclusion}

The conducted research allows us to draw the following conclusion. The activities of the SUEK-Kuzbass JSC over the past five years have a positive trend. The company determines the main production indicators of Leninsk-Kuznetsk city district. The development of the municipality is associated with the activities of the city-forming 
enterprise. For the development of a municipality, it is necessary to use mechanisms of municipal-private partnership that contribute to the development of both the city-forming enterprise and the economy and social sphere of the municipality. The following areas of municipal-private partnership can be considered: development of the investment potential of the city-forming enterprise, development of small business and corporate social responsibility. The measures agreed by the municipality and the city-forming enterprise within these three directions will become an effective tool for the development of the Leninsk-Kuznetsk city district.

\section{References}

1. E. Satybaldina, Journal of Advanced Research in Law and Economics, 6 (2), 372-378 (2015)

2. J. Allen, Company Town in the American West (University of Oklahoma Press, Oklahoma, 1966)

3. Jh. Garner, The Model Company Town (The University of Massachusetts Press, Boston, 1984)

4. H. Green, The Company Town: The Industrial Edens and Satanic Mills that Shaped the American Economy (Basic Books, New-York, 2010)

5. M. Olshausen, From Company Town to Company Town: Holden and Holden Village (Today, Washington, 2013)

6. D. Littlewood, Journal of business ethics, 120 (1), 39-63 (2014)

7. O. Dinius, A. Vergara, Company Towns in the Americas: Landscape, Power, and Working-Class Communities (Athens, Georgia: University of Georgia Press, 2011)

8. M. Tonts, P. Plummer, M. Lawrie, Journal of Rural Studies, 28 3), 288-301 (2012)

9. T.E. Karmanova, E.N. Podsevalova, L.A. Mityurnikova, I.A. Suslova, S.S. Zikirova, International Journal of Applied Business and Economic Research, 15 (8), 163-176 (2017)

10. E. Shvakov, N. Shcherbakova, S. Kulay, Public Administration and Regional Management in Russia, 6, 203-212 (2020)

11. A. Bebbington, L. Hinojosa, D.H. Bebbington, M.L. Burneo, X. Warnaars, Development and Change, 39(6), 887-914 (2008)

12. Syaparman, S. Sri, S. Etty, P. Hartuti, European Journal of Economics and Management Sciences, 3, 39-48 (2019) 